\title{
Doença de Chagas: sucessos e desafios
}

Em junho de 2006, o Brasil recebeu uma certificação relativa à eliminação da transmissão da doença de Chagas pelo principal vetor (Triatoma infestans) e pela via transfusional, concedida pela OPS/OMS. O que fora o sonho maior de Carlos Chagas transformou-se em grande feito, um produto da tenacidade de cientistas e de milhares de anônimos guardas sanitários, saga iniciada por Emmanuel Dias há mais de 60 anos. Nos anos 70 havia no Brasil mais de 5 milhões de brasileiros infectados pelo Trypanosoma cruzi, estimando-se por ano 100 mil casos novos e uma mortalidade superior a 10 mil casos. Apenas $5 \%$ dos bancos de sangue faziam o controle dos doadores e mais de 700 municípios tinham suas casas infestadas pelo T. infestans. A morte era precoce entre adultos jovens, não havia tratamento efetivo. Um problema social enorme, multidões de órfãos e viúvas, de incapacitados pela cardiopatia grave. Os únicos elos vulneráveis da doença eram o inseto vetor, alojado em paupérrimas choupanas rurais, e os bancos de sangue, onde entre 5 e $7 \%$ dos doadores estavam infectados. Na década de 80, uma grande pressão dos cientistas brasileiros levou à priorização de um programa nacional contra a doença, cobrindo-se a área endêmica com inseticida e instalando-se a seleção sorológica nos bancos de sangue. Em 1991, os países do Cone Sul se associaram na luta comum, logrando-se resultados excepcionais no Uruguai, no Chile e em partes da Argentina e do Paraguai. Para ser certificado, o Brasil teve milhões de casas expurgadas e inspecionadas, caindo as capturas de T. infestans de mais de 80 mil no ano de 1979 para pouco mais de 40 exemplares em 2005. Desapareceram os jovens e crianças infectados, chegou-se a $100 \%$ de controle nos bancos de sangue, a prevalência da infecção baixou a $0,65 \%$ dos candidatos à doação. Morrem hoje muito menos "chagásicos" e os remanescentes infectados estão sobrevivendo mais, fruto de avanços na Medicina e maior cobertura da atenção médica. Justos motivos para comemorar.

Não obstante, é dever alertar que o assunto não está terminado, muito há que fazer. O maior perigo das boas notícias reside no ufanismo inconseqüente e no afrouxar das ações. Dificilmente voltará o T. infestans, mas persistem na natureza triatomíneos secundários, que poderão ocupar o nicho da espécie eliminada. A própria eliminação do T. infestans requer consolidação para detectar e destruir focos residuais. Vigilância epidemiológica é a palavra-chave. A partir de 2000, a Reforma Sanitária descentralizou as ações de controle, transferindo-as aos Estados e Municípios. A sistemática da vigilância é a mesma, mas a continuidade das ações não pode ser desfeita. Secretarias municipais e estaduais têm de se aparelhar tecnicamente, alocar recursos e realizar supervisões. Devem capacitar-se para enfrentar situações raras como os surtos de transmissão oral da doença na Amazônia, em Santa Catarina e no Ceará, assim como para monitorar possível resistência de triatomíneos aos inseticidas. Devem cuidar de eventuais casos agudos e congênitos e atender adequadamente às pessoas infectadas no passado. Bancos de sangue precisam seguir controlados. Pesquisas devem prosseguir visando a medicamentos mais eficazes e melhor controle do vetor no peridomicílio. Pergunta-se até quando e quem fará tudo isto. Seguramente umas duas ou três décadas de vigilância se fazem necessárias e o SUS será o grande responsável pela continuidade das ações. O Brasil teve papel fundamental na descoberta da doença e nas pesquisas e serviços que redundaram em sua eliminação. Pode e deve seguir como referência. O embate final passará por uma nova lógica, envolvendo agora outros protagonistas além dos valorosos "guardas" da extinta SUCAM. Gestores, educadores, políticos e pesquisadores são requeridos para o sucesso da nova fase.

João Carlos Pinto Dias

Centro de Pesquisas René Rachou, Fundação Oswaldo Cruz, Belo Horizonte, Brasil. Membro do Comitê de Doenças Parasitárias da Organização Mundial da Saúde. jcpdias@cpqrr.fiocruz.br 